\title{
Den generøse ortodoksi
}

\author{
Theodor Jørgensen
}

Niels Henrik Gregersen: Den generøse ortodoksi: Konflikt og kontinuitet $i$ kristendommen, København, Eksistensen, 2015, 523 sider, 299 kr.

Sjældent har jeg læst mig ind i en bog med så stor samstemmighed, som jeg har gjort det med N.H. Gregersens (NHG) omfattende bog Den generøse ortodoksi, hvor han har samlet en række vægtige, tidligere udgivne afhandlinger og artikler med en række nyskrevne til bogen. NHG er en internationalt anerkendt specialist i spørgsmålet om forholdet mellem teologi og naturvidenskab, men i denne bog træder han frem som den teologiske generalist, han egentlig også er.

Det bliver allerede tydeligt i den titel, han har valgt til bogen, Den generose ortodoksi, som han uddyber i en omfattende indledende afhandling, der er skrevet specifikt til bogen (kap. 1). Det, NHG vil betegne som den generøse ortodoksi, er begrundet $\mathrm{i}$, at kristendommen er en selvbevægelig religion, der udmærker sig ved tre kendetegn: 1. "Kristendommen [er] en religion, der ligesom enhver anden kulturtradition har udviklet sig over tid og sted og fortsat gør det" (18). 2. "Karakteristisk for kristendommen [er], at den altid har formuleret sig i et sprog, som de kristne har delt med de ikke-kristne inden for en større kulturkreds" (19). 3. "Kristendommen [har] internaliseret en Jesus-tradition, der ligger som en farlig tændsats midt i den kristne kanon. Jesus-traditionen er så at sige endog en eksplosiv" (20).

Uden her at kunne gå nærmere ind på de frugtbare analyser, som NHG foretager af teologihistorien i sin nærmere bestemmelse af, hvad den generøse ortodoksi er kendetegnet ved til forskel fra andre opfattelser af ortodoksi, skal NHG’s konklusion nævnes: Ortodoksi som polyfoni (37 
ff.). Den generøse ortodoksi fastholder nødvendigheden af en helhedstolkning af den kristne læretradition, svarende til den kristne bekendelse til den "hellige almindelige (katholikos) kirke". De forskellige stemmer må komme til orde. "Ortodoksi kræver musikalitet, og dertil en god portion balancesans" (11).

Moralen må være, at uanset at det også er nødvendigt, at teologer specialiserer sig for at drive forskningen og en dybere erkendelse af den kristne overlevering i nutidens kontekst videre, kan ingen teolog undgå også at være generalist, hvis ikke han eller hun skal blive enøjet. Dette er Den generøse ortodoksi et prisværdigt eksempel på, idet den i de emner, den behandler, forener det specialiserede syn med det generelle.

$\mathrm{Nu}$ skal denne anmeldelse i Grundtvig-Studier ikke gælde alle bogens kapitler, selv om det ville være fristende. Jeg skal begrænse mig til kapitel 10, 11 og $12 \mathrm{om} \mathrm{Grundtvig.} \mathrm{De} \mathrm{er} \mathrm{i} \mathrm{sig} \mathrm{selv} \mathrm{så} \mathrm{indholdsrige,} \mathrm{at} \mathrm{man} \mathrm{kan}$ undre sig over, at NHG ikke har samlet dem med nogle andre Grundtvigartikler til en monografi. Men det er nu alligevel godt, at han ikke har gjort det. For om nogen hører Grundtvig, som NHG selv gør opmærksom på (12), hjemme i den store sammenhæng som en repræsentant for den generøse ortodoksi.

Kapitel 10 har som overskrift: "Nådespagten og menneskets frihed. N.F.S. Grundtvigs trinitariske nådesteologi” (tidl. trykt i Nåden og den frie vilje, red. Bo Kristian Holm og Else Marie Wiberg Pedersen, Frederiksberg, Anis, 2006, 267-290). Her er NHG's tese, “at Grundtvig bevidst udformer sin nådesteologi på en sådan måde, at han indarbejder aspekter af en moderne kontraktteori i sin tænkning" (213). Jeg vil mene, at NHG med den tese vender op og ned på en hel del tolkninger af Grundtvigs teologi, ikke mindst af hans dåbsteologi. Han knytter til ved Kim Arne Pedersens udforskning af Grundtvigs frihedsbegreb. Der foreligger således et tosidet forhold mellem Guds nåde og menneskets frihed, som "understreges i selve hjertet af Grundtvigs dåbsteologi”, men ikke desto mindre "er et overset træk ved Grundtvigs kristendomsforståelse, som det tyvende århundredes teologi har søgt at nedtone eller ligefrem udradere" (214). Grundtvigs pagtsteologi forudsætter simpelt hen denne gensidighed, som det naturlige menneske er i stand til at gå ind i, fordi det selv i syndefaldet har bevaret sin gudbilledlighed, vel svækket, men dog ikke så meget, "at dets livsvilje og begær efter frelse er ødelagt” (ibid.). 
NHG benægter ikke, at Grundtvig befinder sig i den augustinsk-reformatoriske tradition med besyngelsen af Guds nådes uimodståelige kraft. Men hans "tolkning af denne spænding er, at mens Grundtvigs lovprisning af nådens kraft reflekterer menighedens erfaring af at være befriet af Helligånden, fremhæver Grundtvig nåden som et guddommeligt tilbud til mennesket ved kristenlivets begyndelse. Derfor spiller tilspørgslen ved dåben og konfirmationen så stor en rolle hos Grundtvig" (215). Dette spor forfølger NHG så igennem hele afhandlingen, først ved en sammenligning af Grundtvig og John Wesley som to eksempler på en konditionalistisk nådeslære (215 ff., allerede begrebet vil vække ubehag i visse grundtvigianske øren), dernæst ved en gennemgang af Grundtvigs trinitariske nådesteologi for at munde ud i "Dåbspagten udlagt som en kontrakt mellem Gud og menneske” (223 ff.). "Dåbens ord er altså at forstå som Guds invitation til det skabte, men faldne menneske om at træde ud af synden og ind i nådens rige. Som sådan er evangeliets løfte et tilbud, der ikke voldeligt fratager menneskets dets gudgivne mulighed for at sige ja (eller nej), men taler til det skabte menneske i dets evne og kraft til at sige nej til løgnen og forbinde sig med sandheden, skønheden og godheden i tro, håb og kærlighed. Det er således alene Guds ord, der virkeliggør frelsen, men frelsen er betinget af det naturlige menneskes frie ja til Gud" (226).

Dermed er der også givet en basis for at tale om "Den bejlende Kristus. Grundtvigs konfirmationsteologi” (228 ff.), altså tilkende konfirmationen en særlig teologisk betydning, som en traditionel grundtvigsk dåbsteologi ellers har haft vanskeligheder med, selv om den foreligger klart i salmen "Han, som på jorden bejler" (DDS 479). Konfirmationen ses som troens frivillige bekræftelse af bekendelsen ved dåben, sådan som det er forudsat i forståelsen af nåden som en nådespagt mellem Gud og menneske.

Men det indebærer muligheden for et fravalg fra menneskets side og dermed for fortabelse. Kan Gud ud fra sin uimodståelige nådesvilje affinde sig med det? Næppe, og dermed melder sig et påskelørdags evangelium på banen, Jesu nedfart til dødsriget. Derfor afslutter NHG også sin afhandling med "Grundtvigs store vision om den anden chance" (230 ff.). "Ved nådens ankomst sættes mennesket fri til at vælge. Men ved menneskets genfødelse ved Kristus og Helligånden sættes mennesket fri til også at kunne vælge det rette, om det vil" (233).

Kapitel 11 har som overskrift: "Mennesket som mikrokosmos. N.F.S. Grundtvigs store digt om menneskelivet" (en tidligere version er trykt i 
Grundtvig-Studier 2000, 75-104). Dette store digt fra 1847 findes i GSV IV, nr. 173, og er efter NHG's mening blevet overset i Grundtvigforskningen. Derfor ønsker han at fremdrage det $i$ en grundig gennemgang og analyse af dets 38 strofer. NHG ser i digtet samlet "en række af Grundtvigs grundanliggender, ikke mindst sammenhængen mellem Kristus-billede og menneskesyn. Denne sammenhæng viser sig at rumme både en tidslig dimension af udvikling og en rumlig dimension af natur og sanselighed. Det er i denne sammenhæng, at den gamle tanke om mennesket som et mikrokosmos hører hjemme. For i menneskets lille verden er alting samlet - både ånd og natur" (235 f.).

I det følgende uddyber NHG Grundtvigs forståelse af frelse som både restitution og transformation. Den ved syndefaldet sårede gudbilledlighed skal heles og genoprettes, men der er også "et nyt overskud, som mennesket skal forløses til, nemlig gudbilledlighedens forvandling i Kristus" (236). Det er, hvad Grundtvig senere i Den christelige Børnelardom kalder for "Saliggjørelsens Orden" (f.eks. $V U$ 6, 138), og som åbner for hans tale om Kristi vækst som gudsbarnet i os. Det er denne dobbelthed i forståelsen af frelsen, Grundtvig lærte af oldkirkens teologer, men som af nyere Grundtvigforskning ofte er blevet nedtonet til fordel for forståelsen af frelsen som restitution. Men det er en reduktiv læsning af Grundtvigs frelsesforståelse. For "Det menneske, der er blevet genløst, skal hen ad vejen opdage stadigt nye sider af den visdom, som blev åbenbaret i Kristus" (238).

Det er i tidens og udviklingens perspektiv, at Grundtvig udfolder sit menneskesyn. Men det udelukker på ingen måde, at mennesket også anskues i naturens rumlige kategorier. Det bliver ifølge NHG særligt tydeligt i Grundtvigs digt om "Menneske-Livet", som er komponeret over et fast inventar af naturbilleder. Dog ikke sådan at forstå, "at Grundtvig i digtet udviser nogen selvstændig interesse for konkrete sanseindtryk [...] Naturens fænomener bruges som sindbilleder på menneskelivet [...] Mennesket opfinder ikke, men opdager naturens betydning" (238). Forudsat er her, at Grundtvigs poesi udtrykker en bestemt ontologi. "I sin gudbilledlige bestemmelse afspejler mennesket en sammenføjning af naturens og åndens verden. Mennesket danner således fikspunktet mellem den sanselige og åndelige verden og udgør som sådan et mikrokosmos” (239). Her er det vigtigt for NHG at understrege, at "Grundtvigs hovedinteresse ligger 
således ikke i den horisontale udvikling fra natur til ånd, men i den på forhånd etablerede sammenhæng mellem natur og menneske" (ibid.).

Det er naturligvis ikke muligt at drøfte NHG's indgående analyse og tolkning af digtet "Menneske-Livet", som ellers virker ret overbevisende, i enkeltheder. Vi må lade os nøje med de konklusioner, han drager af sin tolkning. Overraskende for mange vil det nok være, at NHG karakteriserer Grundtvigs forståelse af mennesket som mikrokosmos som platoniskkristen (jf. 251 ff.). Mennesket opfattes her som foreningspunkt mellem naturens sansbare verden og den usynlige åndelige verden. Det er den oldkirkelige tankegang til forskel fra den romantiske, der ser syntese af ånd og natur i mennesket som et resultat af en udvikling. "Mennesket er netop et dobbelt mikrokosmos og har til opgave at være formidler af den dyriske og den guddommelige natur" (253). Alligevel finder NHG i nogle af de tekster, han refererer til, en vis tøven hos Grundtvig over for mikrokosmos-tanken. "Denne tøven skyldes, at mennesket ikke kun rummer sanselighedens, men også åndens verden i sig. Mennesket er krydsfeltet eller krystallisationspunktet, hvor "Overgangen" sker fra de sanselige forestillinger til de åndelige billedrækker" (257). Her er der grund til at minde om, hvad NHG i selve gennemgangen af digtet "Menneske-Livet" gør opmærksom på, at man i forståelsen af mennesket som et dobbelt mikrokosmos må inddrage den kristologiske tonaturlære, udformet på synoden i Chalkedon i år 451: Kristus, der i sig på fuldkommen vis forener den guddommelige og den menneskelige natur, og som sådan er fuldkommengørelsen af mennesket som det dobbelte mikrokosmos. "Kristus er således den dybe sammenhæng i alt, som er til. "Alle ting har deres Samhold i Kristus"” (246).

Det er så også det tankespor, NHG forfølger i sin korte gennemgang af Grundtvigs forhold til Henrich Steffens' version af mikrokosmos-tanken (258 ff.), før han når frem til sin konklusion, "Billedsprogets ontologi i Grundtvigs mikrokosmos-tanke" (261 f.) Her giver han Kim Arne Pedersen medhold i at skelne imellem "den rationelle mikrokosmostanke" og "den billedsproglige mikrokosmostanke" hos Grundtvig, hvor snarere soteriologien end ontologien står i centrum, fordelt på henholdsvis DanneVirke-tiden 1816-19 og senere tiden omkring Sang-Varkets tilblivelse. Alligevel finder NHG sin tolkning holdbar, at "der imidlertid kun [findes] én mikrokosmos-tanke hos Grundtvig, og det er tanken om, at mennesket er samlingspunktet og formidleren mellem naturens og åndens kræfter. 
Grundtvig bygger med andre ord på den dobbelte mikrokosmos-tanke i forlængelse af den platonsk-kristne tradition, og denne har vist sig at være forskellig fra romantikkens potenserede naturbegreb og den deraf følgende immanentisme” (261 f.).

Kapitel 12 har som overskrift "Selvets tilblivelse hos Grundtvig og Kierkegaard” (tidl. trykt i Religion. Tidsskrift for Religionslarerforeningen, 1993, 12-25). NHG ønsker i denne afhandling at tage et tværsnit igennem de to forfatterskaber med henblik på to fundamentale problemstillinger: "Hvordan forstås mennesket som åndsvæsen eller et selv, og hvad er det for et begreb om mulighed, som ligger bag deres forståelse af selvets tilblivelse - "menneskelivets vækst" hos Grundtvig og "eksistensens vorden” hos Kierkegaard?" (263). Den sidstnævnte skelnen kommer meget sigende til udtryk i hovedoverskrifterne af henholdsvis Grundtvigafsnittet - "Grundtvig om Menneskelivets udvikling" - og Kierkegaardafsnittet "Subjektivitetens tilblivelse hos Søren Kierkegaard".

I Grundtvigafsnittet tager NHG igen sit afsæt i Danne-Virke-artiklerne. Udgangspunktet er Grundtvigs tredelte menneskesyn "Aanden som Vxsenet, Legemet som dens Billede, og Sjælen som den i Sandhed forbundne af begge" (DVII, 160). Det er i denne forbundenhed, at mennesket bliver til som et selv. Her får legemet en dobbelt funktion, dels som redskab eller instrument for åndens virke, dels som billede, hvori den åbenbarer sig. Også her fremfører NHG Grundtvigs forståelse af mennesket som mikrokosmos og understreger den teologiske begrundelse i "Skaberåndens organiserende virke i verden, hvad der ikke er det samme som at sige, at naturen har ånd” (265). NHG har ret i, at historisk bedømt er Grundtvig en førmoderne tænker, men påpeger samtidig, at tanken om mennesket som mikrokosmos slet ikke behøver at ligge os så fjern på baggrund af evolutionsteorien. Men Grundtvig afviste "enhver materialistisk ansats til at forklare tilværelsen ud fra "Natur og Tilfælde" og tilskrev i stedet den historiske udvikling "Gud og Forsyn" (DV II, 175)" (266).

Men "Det egentlige kendemærke for mennesket er imidlertid dets bevidsthed om den åndelige verden. Hvor sjælen er menneskets egen, indtil den tilintetgøres ved døden [bliver den nu det hos Grundtvig? Jf. f.eks. $D D S$ 33,6 f.], så har det åndelige en både personlig og overpersonlig karakter" (ibid.).

I det følgende gennemgår NHG så korrespondenserne mellem legemligt og åndeligt hos Grundtvig, som jeg ikke kan gå i enkeltheder med. Han 
uddyber, hvad det platoniske er i Grundtvigs poetik. Ånden har højere rang end legemet, men bruger legemet som sit instrument og udtryksorgan. Dermed er også slået fast, at ånden er en langt større og mere omfattende virkelighed end menneskets bevidsthed, men "Grundtvig er platoniker af den kristne slags, for hvem inkarnationen af de åndelige ideer er helt afgørende" (269).

Men en kendsgerning er, at mennesket, der er ånd, først bliver sig det bevidst undervejs. Grundtvig foretager ifølge NHG en historisering af mikrokosmos-tanken. Det betyder ikke, at det åndelige opstår nedefra, fra driftshavet. "Nej, ånden er en forudgivet og selvstendig realitet, hvis realitet vi dog først kommer til klarhed over i historiens forløb” (270). Deraf følger en forståelse af mulighed som iboende kimkraft i historien, også i det enkelte menneskes historie. Her "tænker Grundtvig tilsyneladende aristotelisk [...] Men fra første færd af er denne aristoteliske kimkrafttænkning fortolket skabelsesteologisk" (272).

Men selv om fortiden gives en vis prioritet i henseende til menneskelivets substantielle indhold, "så gives fremtiden til gengæld prioritet i henseende til realiseringen af menneskets forudgivne potentialer. "Kun fremtiden kan fyldestgjøre Mennesket, give ham et Fuldstandigt og klart Begreb om Mennesket i sin hele fylde" (DVI, 121)" (272).

Jeg ser det ikke her som min opgave at forholde mig til NHG's tolkning af Kierkegaards forstålse af subjektivitetens tilblivelse, der primært tager sit afsæt i indledningen til Sygdommen til Døden, blot nævne, at Kierkegaard ifølge NHG ikke kan sætte Selvets tilblivelse som et håndterbart mål. "Hensigtserklæringer hjælper ikke Selvet til at blive sig selv, men er netop udtryk for, at Selvet faktisk endnu ikke har hjemme hos sig selv. Det er derfor selve processen, der er målet, for kun på stedet kan man blive konkret” (277). Hvad forståelsen af mulighed angår, prioriterer Kierkegaard fremtiden - i bevidstheden om, at fremtiden er uindhentelig ud fra nutidens potentialer, til forskel fra Grundtvig, hvis kimkrafttænkning prioriterer fortiden som ansporing til en nutidig virkeliggørelse (278 f.).

Er Grundtvig så førmoderne og Kierkegaard moderne? På en måde ja, men NHG advarer afslutningsvis mod sådanne etiketteringer, fordi de ofte kommer til at forveksle et idéhistorisk forhold med et filosofisk kriterium. "Det er ikke uden videre givet, at det før-moderne er det illusoriske, det moderne det sande. Både Grundtvig og Kierkegaard skal tages alvorligt som tænkere og ikke blot som idéhistoriske figurer. Herunder må man 
gøre sig klart, at hvis der overhovedet findes noget, som med rette kan kaldes sandt, så står vi per definition over for noget trans-epokalt, uanset om forskellige epoker og forskellige kulturer har opdaget det eller ej" (279).

Jeg har i denne anmeldelse bestræbt mig på at give et overblik over NHG’s Grundtviganalyser og -tolkninger, som også tydeliggør den sammenhæng, der findes i deres intention. De kredser alle om Grundtvigs forståelse af menneskets placering i historien og i verden som et bidrag til den selvafklaringsproces af menneskelivet, som vi alle til stadighed befinder os i. Også de udspringer af den generøse ortodoksi og hører derfor med rette hjemme i denne bog frem for i en særskilt Grundtvigmonografi. Samtidig udvider de betydeligt forståelseshorisonten og tolkningsmulighederne af Grundtvigs tankeunivers i sammenligning med den eksistensteologiske tilgang, som længe var den dominerende i Grundtvigforskningen. 